\title{
Disorders of magnesium metabolism in epilepsy
}

\author{
HORACIO M. CANELAS ${ }^{1}$, LUIIS MARQUES DE ASSIS, AND FRANCISCO B. DE JORGE \\ From the Departments of Neurology and Medicine, University of São Paulo \\ School of Medicine, São Paulo, Brazil
}

Clinical observations in man (Griffiths, 1947; Randall, Rossmeisl, and Bleifer, 1959; Hanna, Harrison, MacIntyre, and Fraser, 1960; Vallee, Wacker, and Ulmer, 1960) and experimental investigations in animals (Kruse, Orent, and McCollum, 1932) have shown that magnesium (Mg) depletion causes a marked irritability of the nervous system, eventually resulting in epileptic seizures. The possibility that convulsions may occur in $\mathbf{M g}$ deficiency led some investigators to study the metabolism of this metal in the epilepsies, and a trend to low blood concentrations was usually found (Denis and Talbot, 1921; Blumgarten and Rohdenburg, 1927; Hirschfelder and Haury, 1934, 1935; Haury, 1942; Suter and Klingman, 1955). In successive studies, Hirschfelder and Haury $(1935,1938)$ found a lowering of $\mathrm{Mg}$ and a rise of potassium in the blood of epileptic patients, leading to a definite increase in the $\mathrm{K} / \mathrm{Mg}$ ratio, proportional to the severity of the disease. Concerning the metabolism of magnesium in the cerebrospinal fluid, Cohen (1927), McCance and Watchorn (1931), and Greenberg and Aird (1938) found in epilepsy the same range of magnesium levels as in other nervous diseases. Hirschfelder and Haury (1938) found low concentrations of $\mathrm{Mg}$ in the cerebrospinal fluid of epileptic patients, though the levels were higher than in the blood.

These findings, associated with the fact that $\mathbf{M g}$ is a known depressor of the central nervous system and is involved in several enzymatic processes, including the synthesis of acetylcholine, were not appreciated by some authorities in the field of epilepsy, even when the neurochemistry of this disease was analysed (Tower, 1960).

\section{MATERIAL AND METHODS}

Two groups of patients, including 83 cases of epilepsy and 34 of mental disease (mostly schizophrenics), were studied.

The neurological examination was normal in all the epileptic patients and no sign of intracranial hypertension

2Present address: Department of Neurology, Caixa Postal 3461, São Paulo, SP, Brazil. was present. They were from 9 to 56 years old; 44 were males, and 39 females; 67 .were white, nine were negroes, and seven were mulattoes. Convulsive manifestations were reported by 71 patients; in 14 the seizures had a centroencephalic pattern and, in 57 they resulted from diffusion of focal discharge; among the latter, 11 patients showed concomitant psychomotor fits. Four patients had only petit mal absences; one had myoclonic petit mal; two had only psychomotor fits. In four cases the seizures were not well characterized from the clinical viewpoint. In one case no epileptic manifestations were reported but the electroencephalogram evidenced a temporal focus.

The epileptic patients were divided into two subgroupsIn the first set (cases 1 to 80), blood (79 cases) and cerebro spinal fluid (78 cases) were sampled to determine $M \mathbb{B}$ levels in the period between seizures. In the second sef of patients, blood (eight cases) and cerebrospinal fluid (four cases) were sampled immediately after the seizure or during status epilepticus.

Electroencephalograms were recorded in 76 cases. In 25 patients the tracings were normal, in 36 focal abnor malities were recorded, and in 15 the changes were diffuse

In the mental patients, blood ( 34 cases) and cerebrospinal fluid (nine cases) were sampled just before and after the electroshock (complete crisis) in the postconvulsive coma.

Cerebrospinal fluid was always collected through cisternal puncture. Magnesium was determined according to the method of yellow titan in alkaline solution, slightly modified (De Jorge, Silva, and Cintra, 1964b). The results were compared with the normal concentrations determined by the same method (De Jorge, Canelas, and Zanini, 1964a).

\section{RESULTS}

The results, submitted to conventional statistical analysis, are summarized in Tables I, II, and III.

The existence of hypomagnesaemia in epilepsy, at the interseizure period, was confirmed (Table I). The study of the statistical correlations showed that the blood $\mathrm{Mg}$ concentration was lower when the time elapsed after the last convulsion was shorter (Table II).

Although no significant correlation was found with the frequency of fits, our results agree, in a general way, with the findings of Hirschfelder and Haury $(1935,1938)$. The frequency of fits showed a 
TABLE I

AVERAGE CONCENTRATIONS OF MAGNESIUM (mEq./l.) IN THE BLOOD AND CEREBROSPINAL FLUID IN CASES OF EPILEPSY

\begin{tabular}{|c|c|c|c|c|c|c|c|}
\hline \multirow[t]{2}{*}{ Variables } & \multirow[t]{2}{*}{ No. of Cases } & \multirow[t]{2}{*}{ Mean } & \multirow[t]{2}{*}{ $\pm S . D}$. & \multirow[t]{2}{*}{ Range } & \multicolumn{3}{|c|}{ Significance of the Difference of Means } \\
\hline & & & & & $t^{1}$ & d.f. ${ }^{1}$ & $P$ \\
\hline Blood $\left\{\begin{array}{l}\text { Epilepsy } \\
\text { Normal }\end{array}\right.$ & $\begin{array}{r}79 \\
130\end{array}$ & $\begin{array}{l}1 \cdot 868 \\
2 \cdot 087\end{array}$ & $\begin{array}{l}0.202 \\
0.067\end{array}$ & $\begin{array}{l}1.466-2.429 \\
1.916-2.185\end{array}$ & $9 \cdot 340$ & 89 & $<0.001$ \\
\hline $\begin{array}{l}\text { Cerebrospinal } \\
\text { fluid }\end{array}\left\{\begin{array}{l}\text { Epilepsy } \\
\text { Normal }\end{array}\right.$ & $\begin{array}{l}78 \\
36\end{array}$ & $\begin{array}{l}2 \cdot 419 \\
2 \cdot 266\end{array}$ & $\begin{array}{l}0.270 \\
0.061\end{array}$ & $\begin{array}{l}1 \cdot 721-2 \cdot 986 \\
2 \cdot 178-2 \cdot 360\end{array}$ & $4 \cdot 747$ & 90 & $<0.001$ \\
\hline
\end{tabular}

${ }^{1} t$ test for independent samples assuming unequal variances (Dixon and Massey, 1957).

negative correlation with the time after the last seizure, as could be expected (Table II). However, the low level of significance $(\mathrm{P} \simeq 0.04)$ of this coefficient may explain the absence of a negative correlation between the $\mathrm{Mg}$ content and the frequency of fits. Concerning the cerebrospinal fluid, however, our results did not quite agree with those of the literature since a significant increase of the $\mathrm{Mg}$ content in this fluid was found (Table I). An unexpected finding was the positive correlation between the $\mathrm{Mg}$ concentration in the blood and in the cerebrospinal fluid ' (Table II). In this fluid the Mg contents were not significantly correlated with either the frequency or with the time interval after the last seizure.

\section{TABLE II}

BLOOD AND CEREBROSPINAL FLUID MAGNESIUM CONCENTRATIONS IN EPILEPSY CORRELATED WITH THE YEARLY FREQUENCY OF FITS AND THE TIME AFTER THE LAST SEIZURE

Variables

$r$

Significance of Correlations

t d.f. $P$

Blood $\mathrm{Mg} /$ frequency of fits

Blood $\mathrm{Mg} /$ time after last

seizure

Cerebrospinal fluid $\mathbf{M g}$ /

frequency of fits

- Cerebrospinal fluid $\mathrm{Mg}$ / time

after last seizure

Frequency of fits/time after

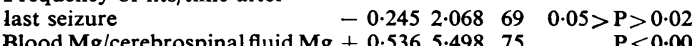

The concentrations of $\mathrm{Mg}$ in the blood and in the cerebrospinal fluid of patients with normal, diffuse, or focal electroencephalographic patterns did not show significant differences (Table III). Likewise, the concentrations of blood and cerebrospinal fluid magnesium in post-convulsive cases and in status epilepticus were not significantly different from the levels of the same patients at the interseizure period (mean difference in the blood $=-0.035 \pm 0.297$ mEq./l., $\mathrm{t}=0.327 ; 0.8>\mathrm{P}>0.7$; mean difference in the cerebrospinal fluid $=-0.071 \pm 0.252 \mathrm{mEq} . / \mathrm{l}$., $\mathrm{t}=0.563 ; 0.7>\mathrm{P}>0.6$ ).
TABLE III

AVERAGE CONCENTRATIONS OF MAGNESIUM IN THE BLOOD AND CEREBROSPINAL FLUID IN DIFFERENT ELECTROENCEPHALOGRAPHIC PATTERNS AND SIGNIFICANCE OF THE DIFFERENCES BETWEEN THEM

E.E.G. No. Mean \pm S.D. Significance of the Differences $\left(t^{1}\right)$

\begin{tabular}{|c|c|c|c|c|}
\hline \multirow{3}{*}{ Blood } & Diffuse & 15 & $1.895 \pm 0.231$ & - Focal $=0.022$ \\
\hline & Focal & 35 & $1.879 \pm 0.210$ & - Normal $=0.253$ \\
\hline & Normal & 25 & $1.836 \pm 0.189$ & - Diffuse $=0.858$ \\
\hline ro- & Diffuse & 14 & $2.395 \pm 0.472$ & - Focal $=0.355$ \\
\hline & & 35 & $2.439 \pm 0.314$ & - Normal $=0.631$ \\
\hline fluid & Normal & 25 & $2.391 \pm 0.248$ & - Diffuse $=0.034$ \\
\hline
\end{tabular}

${ }^{1}$ As the whole level of significance adopted was $a=5 \%$, we worked in the individual independent tests, with the level $a=5 / 3 \%$ (Steel and Torrie, 1960).

In the second group of patients, after electroshockinduced convulsions the $\mathrm{Mg}$ contents showed an increase both in the blood and in the cerebrospinal fluid (mean difference in the blood $=+0.472 \pm$ $0.201 ; \mathrm{t}=13.681 ; \mathrm{P}<0.001$; mean difference in the cerebrospinal fluid $=+0.307 \pm 0.121 ; \mathrm{t}=$ $7.595 ; \mathrm{P}<0.001)$.

\section{DISCUSSION}

Notwithstanding the numerous studies on $\mathrm{Mg}$ metabolism, their interpretation is still obscure. Magnesium is the fourth most abundant cation of the human body. If only the intracellular component is analysed, $\mathrm{Mg}$ is the second most frequent cation, following potassium (MacIntyre, 1959; Clough, 1960). The views on the interpretation of the $\mathrm{Mg}$ depletion syndrome are still conflicting, the condition being ascribed either to a fall of the intracellular $\mathbf{M g}$, with a lowering of the intracellular/extracellular ratio (Clough, 1960), or to a depletion of the extracellular concentration, in a way very similar to the behaviour of sodium (Suter and Klingman, 1955).

If an inhibition of acetylcholine synthesis by $\mathbf{M g}$ was assumed to occur at the cerebral level, as it happens at the periphery (Del Castillo and Engbaek, 1954; Hutter and Kostial, 1954; Maurat, 1958), then it could be understood why, in the $\mathrm{Mg}$ depletion syndrome and in epilepsy, acetylcholine is more 
easily liberated. Furthermore, it must be remembered that the nerve cell depolarization is easier when the electric potential difference between the outer and the inner surfaces of the membrane is lower. The inner surface being positive, and the outer surface negative, lower extracellular concentrations of $\mathbf{M g}$ in regard to the intracellular $\mathrm{Mg}$ induce a fall of the potential difference and thus a trend to depolarization. This fact is probably closely related to the liberation of acetylcholine: low concentrations of $\mathrm{Mg}$ lead to a decrease of the electric gradient between the outer and inner surfaces of the cell membrane and to an increase in the amount of liberated acetylcholine, enhancing discharge; when the extracellular concentration of $\mathrm{Mg}$ is high, the transmembrane potential difference is raised, the liberation of acetylcholine falls, and so the cell is protected against the discharge.

Even in normal conditions (De Jorge et al., 1964a) or in nervous diseases other than epilepsy (Cohen, 1927; McCance and Watchorn, 1931), $\mathrm{Mg}$ is found in higher concentration in the cerebrospinal fluid than in the blood. In the epileptic patients this ratio is higher than in normals.

The interpretation of this fact is difficult too, owing to the paucity of knowledge concerning $\mathbf{M g}$ metabolism in general. Kemény, Boldizsár, and Pethes (1961), studying in dogs the distribution of cations in the blood and cerebrospinal fluid after infusion of saline solutions, found that $\mathrm{Mg}$ is unable to cross the blood-cerebrospinal fluid barrier in normal conditions. This fact is of fundamental significance, for it leads to the assumption that the changes of $\mathrm{Mg}$ in the cerebrospinal fluid depend on metabolic processes which take place in the nervous tissue. On these grounds, it could be assumed that, in epilepsy, the $\mathrm{Mg}$ concentration in the cerebrospinal fluid would rise as a consequence of its transference from the intra- to the extracellular compartment.

In the mental patients, after electroshock-induced convulsions, apparently paradoxical results were found in the blood, since the Mg content showed an increase. Nevertheless, this is not a new finding. Wacker (see Walker and Walker, 1936) had already found a marked rise of the blood $\mathrm{Mg}$ as a result of forceful muscular activity electrically elicited in animals. Sacco (1957) found a fall in the blood potassium content just after electroshockinduced convulsions; as the behaviour of this cation is opposite to $\mathrm{Mg}$, one could actually expect a rise of $\mathrm{Mg}$ in such conditions.

The interpretation of our results, however, is evidently mere conjecture, because, during the epileptic crisis, changes in the blood-cerebrospinal fluid barrier probably occur. Moreover, our material comprises two groups of cases evidencing very dis $\bar{z}$ tinct patho-physiological features, namely, epileptic. patients with disorders of $\mathrm{Mg}$ metabolism, an schizophrenics with a seemingly normal $\mathrm{Mg}$ meta bolism. In any event, further studies, including the use of curare during the performance of electros shock, will eventually throw more light on the problem.

SUMMARY

Magnesium metabolism was studied in 83 epilepti patients and in 34 cases of mental disease (mostly schizophrenics) submitted to electroshock. In the first group of patients, the $\mathrm{Mg}$ contents of blood and cerebrospinal fluid were compared with tho severity of the epilepsy and the electroencephalo $\overrightarrow{0}$ graphic pattern.

The following conclusions were drawn. (1) At the $\overrightarrow{\omega_{j}}$ interseizure period the $\mathrm{Mg}$ concentration is low in the blood serum and high in the cerebrospinal fluid (2) The $\mathrm{Mg}$ level in the blood is as low as the time elapsed after the last seizure is shorter. (3) There are no significant differences in the $\mathrm{Mg}$ levels in the blood and cerebrospinal fluid when patients wits normal or abnormal electroencephalographic p@io terns are compared. (4) In the mental patients the $\mathrm{gg}^{2}$ concentrations increase both in the blood and gin the cerebrospinal fluid just after the complete crisig elicited through electroshock.

A tentative interpretation of these results is vanced, especially based on the depolarizing effecto of hypomagnesaemia and on the possibility of a greater liberation of acetylcholine under such con-므 dition.

We are deeply indebted to Dr. Rubens Murillo Marques from the Department of Statistics of the University of São Paulo School of Hygiene and Public Health, for his advice and technical assistance in the execution of the statistical analysis of our material.

\section{REFERENCES}

Blumgarten, A. S., and Rohdenburg, G. L. (1927). Mineral sak: content of the blood in disease. Arch intern. Med, 39, 372-384

Clough, P. W. (1960). Magnesium deficiency. Ibid., 53, 615-620.

Cohen, H. (1927). The magnesium content of the cerebrospinal and other body fluids. Quart. J. Med., 20, 173-186.

De Jorge, F. B., Canelas, H. M., and Zanini, A. C. (1964a). Metabclismo do magnésio. II. Valôres normais no sôro, plasma, sangue total, liquido cefalorraqueano, urina e fezes. Rev. paul. Med.은 65, 95-105.

- Silva, A. G. da, and Cintra, A. B. de (1964b). Determinação

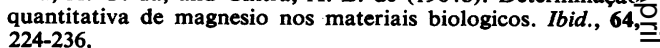

Del Castillo, J., and Engbaek, L. (1954). The nature of the neuromuscular block produced by magnesium. J. Physiol. (Lond.), 124, 370-384.

Denis, W., and Talbot, F. B. (1921). Calcium in the blood of children. Amer. J. Dis. Child., 21, 29-37. 
Dixon, W. J., and Massey, F. J. Jr. (1957). Introduction to Statistical Analysis, 2nd ed., p. 122. McGraw-Hill, New York.

Greenberg, D. M., and Aird, R. B. (1938). Blood and spinal fluid magnesium and calcium levels in epilepsy and convulsive states. Proc. Soc. exp. Biol. (N.Y.), 37, 618-620.

Griffiths, W. J. Jr. (1947). Audiogenic fits produced by magnesium deficiency in tame domestic Norway rats and in wild Norway and Alexandrine rats. Amer. J. Physiol., 149, 135-141.

Hanna, S., Harrison, M., MacIntyre, I., and Fraser, R. (1960). The syndrome of magnesium deficiency in man. Lancet, 2, 172-176.

Haury, V. G. (1942). Variations in serum magnesium in health and disease: a review. J. Lab. clin. Med., 27, 1361-1375.

Hirschfelder, A. D., and Haury, V. G. (1934). Clinical manifestations of high and low plasma magnesium. J. Amer. med. Ass., 102, 1138-1141.

$-,-1935)$. Variations in plasma magnesium and potassium in epilepsy. Proc. Soc. exp. Biol. (N.Y.), 33, 40-42.

- (1938). Variations in magnesium and potassium associated with essential epilepsy. Arch. Neurol. Psychiat. (Chic.), 40, 66-78.

Hutter, O. F., and Kostial, K. (1954). Effect of magnesium and calcium ions on the release of acetylcholine. J. Physiol. (Lond.), 124, 234-241.

Kemény, A., Boldizsár, H., and Pethes, G. (1961). The distribution of cations in plasma and cerebrospinal fluid following infusion of solutions of salts of sodium, potassium, magnesium and calcium. J. Neurochem., 7, 218-227.
Kruse, H. D., Orent, E.R., and McCollum, E. V. (1932). Studies on magnesium deficiency in animals. I. Symptomatology resulting from magnesium deprivation. J. biol. Chem., 96, 519-539.

Maurat, J. P. (1958). Le Magnésium en Pathologie. L'Expansion scientifique française, Paris.

MacIntyre, I. (1959). Some aspects of magnesium metabolism and magnesium deficiency. Proc. roy. Soc. Med., 52, 212-214.

McCance, R. A., and Watchorn, E. (1931). Inorganic constituents of cerebrospinal fluid. I. Calcium and magnesium. Quart.J. Med., 24, 371-379.

Randall, R. E., Rossmeisl, E. C., and Bleifer, K. H. (1959). Magnesium depletion in man. Ann. intern. Med., 50, 257-287.

Sacco, F. (1957). Variazioni protidemiche ed elettrolitiche da elettroshock-terapia. Lav. neuropsichiat., 21, 295-325.

Steel R. G. D., and Torrie, J. H. (1960). Principles and Procedures of Statistics, pp. 106-107. McGraw-Hill, New York.

Suter, C., and Klingman, W. O. (1955). Neurologic manifestations of magnesium depletion states. Neurology (Minneap.), 5, 691-699.

Tower, D. B. (1960). Neurochemistry of Epilepsy. Thomas, Springfield, Illinois.

Vallee, B. L., Wacker, W. E. C., and Ulmer, D. D. (1960). The magnesium deficiency tetany syndrome in man. New Engl. $J$. Med., 262, 155-161.

Walker, B. S., and Walker, E. W. (1936). Normal magnesium metabolism and its significant disturbances. J. Lab. clin. Med., 21, 713-720.

\section{The June 1965 Issue}

\section{THE JUNE 1965 ISSUE CONTAINS THE FOLLOWING PAPERS}

A study of normal nerve action potentials using an averaging technique (barrier grid storage tube) R. W. GILLIATT, I. D. MELVILLE, A. S. VELATE, and R. G. WILLISON

Studies in man and cat of the significance of the $\mathrm{H}$ wave R. F. MAYER and C. MAWDSLEY

Serum cholesterol linoleate levels in multiple sclerosis R. W. R. BAKER, HAZEL SANDERS, R. H. S. THOMPSON, and K. J. ZILKHA

Studies of blood groups, genetic linkage, trait association, and chromosomal pattern in multiple sclerosis DAVID C. POSKANZER, KURT SCHAPIRA, RONALD A. BRACK, and HENRY MILLER

Independence of central controls of vascular and sweat gland responses in the paw of the cat B. J. PROUT, J. H. COOTE, and C. B. B. DOWNMAN

Anatomical pathways related to the clinical findings in aneurysms of the anterior communicating artery JAMES ARTHUR TAREN
Occlusion of the vertebral artery TETSUO TATSUMI and HENRY A. SHENKIN

Studies by fluorescence photography of papilloedema in malignant hypertension C. T. DOLLERY, C. M. MAILER, and J. v. HODGE

Hydrodynamic mechanism of syringomyelia: its relationship to myelocele W. JAMES GARDNER

Progressive multifocal leucoencephalopathy s. B. CHANDOR, L. S. FORNO, and N. A. WIVEL

Myoclonus and ataxia occurring in a family HAROLD JACOBS

Squamous cell carcinoma developing in an intracranial epidermoid cyst (cholesteatoma) H. FOX and E. A. SOUTH

Neuropsychiatric manifestations of chronic manganese poisoning S. ABD EL NABY and M. HASSANEIN

Book reviews

Copies are still available and may be obtained from the PUBLISHING MANAGER, BRITISH MEDICAL ASSOCIATION, TAVISTOCK SQUARE, W.C.I, price 18s. 6D. 